University of Pennsylvania Carey Law School

Penn Law: Legal Scholarship Repository

Faculty Scholarship at Penn Law

$1-2008$

\title{
The Ancient Roots of Modern Financial Innovation: The Early History of Regulatory Arbitrage
}

Michael S. Knoll

University of Pennsylvania Carey Law School

Follow this and additional works at: https://scholarship.law.upenn.edu/faculty_scholarship

Part of the Economic History Commons, Finance and Financial Management Commons, Law and Economics Commons, Legal History Commons, and the Property Law and Real Estate Commons

\section{Repository Citation}

Knoll, Michael S., "The Ancient Roots of Modern Financial Innovation: The Early History of Regulatory Arbitrage" (2008). Faculty Scholarship at Penn Law. 47.

https://scholarship.law.upenn.edu/faculty_scholarship/47

This Article is brought to you for free and open access by Penn Law: Legal Scholarship Repository. It has been accepted for inclusion in Faculty Scholarship at Penn Law by an authorized administrator of Penn Law: Legal Scholarship Repository. For more information, please contact PennlawIR@law.upenn.edu. 
MICHAEL S. KNOLL*

\section{The Ancient Roots of Modern Financial Innovation: The Early History of Regulatory Arbitrage}

$\mathrm{R}$ ecent years have seen an explosion in financial innovation. ${ }^{1}$ The typical, contemporary American investor has access to financial services and instruments, such as exchange-traded stock funds ("ETFs"), Treasury inflation-protected securities ("TIPS"), and socially responsible index funds, that did not exist a generation ago. ${ }^{2}$ Less obvious, but of equal significance, are mortgage-backed securities and related developments that allow lenders to hedge their interest rate risk. These developments have made it possible for lenders to provide fixed-rate home

\footnotetext{
* Theodore Warner Professor, University of Pennsylvania Law School Professor of Real Estate, the Wharton School, Co-Director, Center for Tax, Law \& Policy, University of Pennsylvania. I thank Bernie Black, Peter Huang, Michael McMillen, Deborah Paul, Paul Stephan, Josef Stern, Eric Talley, and George Triantis; audiences at ALEA, Bocconi, Columbia, Georgetown, Rutgers, USC, and Virginia; and my corporate finance students over the years for their many helpful comments and suggestions. I also thank Alvin Dong, Miykaa'iyl Ibn-Ishmawiyl, Benjamin Meltzer, and Lisa Junghanh for their research assistance.

1 Franklin Allen \& Douglas Gale, Financial InNOVATION AND Risk SHARING 3 (1994). For surveys of financial innovations, see id. at 17-31; Peter Tufano, Financial Innovation, in HANDBOOK OF THE ECONOMICS OF FINANCE 307, 311-12 (George M. Constantinides et al. eds., 2003). For a survey of the nascent empirical literature on financial innovation, see W. Scott Frame \& Lawrence J. White, Empirical Studies of Financial Innovation: Lots of Talk, Little Action?, 42 J. ECON. LIT. 116 (2004).

2 See AlLEN \& GALE, supra note 1, at 3-4.
} 
mortgages at lower rates than otherwise possible during times of interest volatility. ${ }^{3}$

The impact of financial innovation has been even greater on Wall Street, which designs and sells innovative financial contracts and establishes the markets where these contracts trade, and Main Street, which has been an enthusiastic customer. Many large companies use credit derivatives, Eurobonds, interest-rate swaps, securitizations, and other recent financial innovations to reduce borrowing costs, hedge risk, increase earnings, reduce taxes, and speculate (sometimes with disastrous results) on price movements.

The principle that underlies the rapid pace of financial innovation is that cash flows can be disaggregated and rebundled in almost unlimited combination. ${ }^{5}$ Not surprisingly, the rush of new financial products has created nightmares for regulators, who must fit new innovations into existing categories. ${ }^{6}$ The pressure is not incidental. The exploitation of regulatory inconsistencies is a major impetus for financial innovation. Indeed, it might be the primary impetus. ${ }^{8}$ There is a strong incentive to innovate around prohibited or disadvantaged transactions. These innovations are commonly referred to as regulatory arbitrage.

3 See John D. Finnerty, An Overview of Corporate Securities Innovation, 4 J. APPLIED CORP. FIN. 23, 25 (1992).

4 See id. at 24-37 (describing recent innovations and their uses).

5 See Robert L. MCDonald, Derivatives Markets 3-4, 463 (2003).

6 See, e.g., Mark P. Gergen, Afterword, Apocalypse Not?, 50 TAX L. REV. 833, 833 (1995); Reed Shuldiner, A General Approach to the Taxation of Financial Instruments, 71 TEX. L. REV. 243, 245 (1992) (describing the tax law's struggle to keep up with the pace of financial innovation).

7 See Clifford W. Smith, Jr. \& Charles W. Smithson, Financial Engineering: An Overview, in THE HANDBOOK OF FINANCIAL ENGINEERING 3, 10-12 (Clifford W. Smith, Jr. \& Charles W. Smithson eds., 1990) (providing four rationales for financial innovation: tax and regulatory arbitrage, classic arbitrage, reducing the expected costs of financial distress, and increasing the corporation's debt capacity).

8 See Merton H. Miller, Financial innovations AND Market Volatility 5-9 (1991). Merton Miller, who shared the 1990 Noble Prize in Economics, argues this point.

${ }^{9}$ For example, inconsistencies in the tax treatment of financial contracts are well recognized and have produced an extensive literature. See, e.g., David F. Bradford, Fixing Realization Accounting: Symmetry, Consistency and Correctness in the Taxation of F inancial Instruments, 50 TAX L. REV. 731 (1995) (proposing a method of imposing a consistent income tax); David M. Schizer, Balance in the Taxation of Derivative Securities: An Agenda for Reform, 104 COLUM. L. REV. 1886 (2004) 
Until recently, it was widely believed that most recent financial innovations were distinctly modern without direct antecedents. $^{10}$ One reason for this view is that many financial innovations rely on option theory, which is of recent vintage ${ }^{11}$ and mathematically sophisticated. ${ }^{12}$ In general, option theory is not accessible without training in advanced mathematics and many of its results are not readily intuitive. However, in a series of recent articles, leading finance experts have traced some recent innovations-many of which are based on option theory-back to the innovations' roots. This literature has succeeded in tracing some innovations back as far as four hundred years. ${ }^{13}$

This Article contributes to that literature by tracing the roots of one specific application of one well-known technique. The technique is put-call parity. The put-call parity theorem states that given any three of the four following financial instrumentsa zero-coupon bond, a share of stock, a call option ("call") on the stock, and a put option ("put") on the stock-the fourth instrument can be replicated. ${ }^{14}$ Thus, the theorem implies that any financial position that contains these assets can be constructed in at least two different ways.

(arguing for balance because consistency is impossible); Herwig J. Schlunk, Little Boxes: Can Optimal Commodity Tax Methodology Save the Debt-Equity Distinction?, 80 TEX. L. REV. 859 (2002); Shuldiner, supra note 6, at 245 (describing tax rules for financial instruments as "haphazard, incomplete, and inconsistent"); Jeff Strnad, Taxing New Financial Products: A Conceptual Framework, 46 STAN. L. REV. 569, 587-93 (1994) (demonstrating that the tax treatments of debt and equity are inconsistent); Alvin C. Warren, Jr., Taxation of Options on the Issuer's Stock, TAXES, Mar. 2004, at 47 (tax treatment of issuer's options are inconsistent with treatments of issuer's debt and equity); David A. Weisbach, Line Drawing, Doctrine, and Efficiency in the Tax Law, 84 CORNELL L. REV. 1627 (1999) (acknowledging that consistency is not possible).

10 E.g., MiLleR, supra note 8, at 5.

11 See Fischer Black \& Myron Scholes, The Pricing of Options and Corporate Liabilities, 81 J. POL. ECON. 637 (1973) (the seminal work on the subject).

12 A few minutes with a graduate-level text should convince most readers of the field's mathematical sophistication. See, e.g., JOHN C. Hull, Options, Futures, AND OTHER DERIVATIVES (4th ed. 2000); MCDONALD, supra note 5.

13 E.g., Allen \& GALE, supra note 1, at 11-43; William L. Silber, FinANCIAL InNOVATION (1975); Peter Tufano, Business Failure, Judicial Intervention, and Financial Innovation: Restructuring U.S. Railroads in the Nineteenth Century, 71 Bus. Hist. REV. 1 (1997); Tufano, supra note 1, at 311-12; Peter Tufano, Securities Innovation: A Historical and Functional Perspective, 7 J. APPLIED CORP. FIN. 90 (1995).

14 See infra Part I (discussing put-call parity theorem). 
Professor Hans Stoll first described put-call parity in 1969. His article, "The Relation Between Put and Call Option Prices," ${ }^{15}$ is deservedly a classic. ${ }^{16}$ It has produced an extensive academic literature and is the source of many important innovations. ${ }^{17}$

The application of put-call parity described in this Article is its use to avoid usury by synthesizing a loan. Although first described in the academic literature less than forty years ago, put-call parity is more intuitive than many ideas in option theory. Because it is so intuitive, the principle was being used before it was formally described:

Put-call parity has been known for at least 100 years. Legend has it that the relationship was discovered by one Russell Sage, an extremely successful businessman in the 19th century. At one point, state usury laws prohibited him from making a high-interest-rate loan to a customer, so he bought stock in a publicly traded company from the customer at the market price. Simultaneously, he bought a put and wrote a call on the underlying stock at fictitious prices, where the customer took the opposite side of each transaction. This provided $\mathrm{Mr}$. Sage with a guaranteed rate of return on his investment . . . . The customer, by always taking the opposite side, was effectively borrowing at this guaranteed rate. The prices of the options were set so that the rate of return to Mr. Sage was above what the usury laws allowed. Bank examiners did not prohibit this complex transaction, because they could not figure out that it was a loan in disguise.

15 Hans R. Stoll, The Relation Between Put and Call Option Prices, 24 J. FiN. 801 (1969).

16 See Douglas G. Baird, The Future of Law and Economics: Looking Forward, 64 U. CHI. L. REV. 1129, 1131 (1997) (arguing that trading in the options and derivatives markets rests upon put-call parity).

17 See Michael S. Knoll, Put-Call Parity and the Law, 24 CArdozo L. Rev. 61, 78-83, 85-89 (2002) (discussing how put-call parity has been used in recent years for regulatory arbitrage and how modern financial innovations use put-call parity to exploit inconsistencies in the tax law); see also David F. Levy, Towards Equal Tax Treatment of Economically Equivalent Financial Instruments: Proposals for Taxing Prepaid Forward Contracts, Equity Swaps, and Certain Contingent Debt Instruments, 3 FLA. TAX. REV. 471, 511-12 (1997); Deborah L. Paul, Another Uneasy Compromise: The Treatment of Hedging in a Realization Income Tax, 3 FLA. TAX REV. 1, 29-34 (1996); David M. Schizer, Frictions As a Constraint on Tax Planning, 101 ColuM. L. REV. 1312 (2001); Alvin C. Warren, Jr., Commentary, Financial Contract Innovation and Income Tax Policy, 107 HARV. L. REV. 460 (1993).

18 STEPHEN A. ROSS, RANDOLPH W. WESTERFIELD \& JEFFREY JAFFE, CORPORATE FINANCE 554 (4th ed. 1999). 
The thesis of this Article is that put-call parity has been used to engage in regulatory arbitrage for much longer than previously believed. This Article traces the use of put-call parity to evade usury restrictions back two thousand years. ${ }^{19}$ This Article also describes the important role put-call parity played in developing the modern mortgage.

\section{THE PUT-CALl PARITY THEOREM}

\section{A. The Basic Instruments}

This Part describes the put-call parity theorem. ${ }^{20}$ The first step in illustrating the theorem is to describe the four financial instruments that are its components. These four instruments are a zero-coupon bond, a share of common stock (also called the underlying asset for a reason that will soon be apparent), a call on the stock, and a put on the stock. The call and the put both have exercise prices equal to the face value of the zero-coupon bond. The two options and the bond all mature on the same date.

\section{B. An Intuitive Proof of the Put-Call Parity Theorem ${ }^{21}$}

The put-call parity theorem states that the payoff from a portfolio consisting of one share of stock, and the right to sell that share (at date $\mathrm{T}$ for exercise price $\mathrm{E}$ ), is equivalent to that from a portfolio consisting of a zero-coupon bond (that pays $\mathrm{E}$ at date $\mathrm{T}$ ), and the right to buy one share of stock (at date $\mathrm{T}$ for exercise price $\mathrm{E})^{22}$

Using the convention that a subscript $\mathrm{T}$ indicates the payoff from holding an instrument at maturity and allowing $\mathrm{S}$ to denote the underlying stock, $\mathrm{P}$ a put on that stock and $\mathrm{C}$ a call, both with expiration date $\mathrm{T}$ and exercise price $\mathrm{E}$, and $\mathrm{E}$ a zero-coupon bond that pays $\mathrm{E}$ at date $\mathrm{T}$, then the put-call parity theorem

\footnotetext{
19 Throughout this Article, I use the terms evasion and avoidance interchangeably. Specifically, I do not make the distinction, well-known in tax law literature, between permissible planning (avoidance) and impermissible planning (evasion).

20 Readers familiar with put-call parity may want to skip ahead to infra Part II.

21 See Ross, WESTERFIELD \& JAFFE, supra note 18, at 552-54 (showing an informal proof of the put-call parity theorem along the lines described below).

22 Id. at 552-54, 662-62.
} 
implies that the payoffs from the four securities at maturity have the following relationship:

$$
E+C_{T}=S_{T}+P_{T}
$$

Using $\operatorname{PV}(\mathrm{E})$ to denote the market price of a bond that will pay $E$ at date $T$, ${ }^{23}$ the claim that the market prices of the two portfolios at any date prior to maturity are equal can be written as follows:

$$
P V(E)+C=S+P
$$

where $\mathrm{S}$ is the market price of the stock and $\mathrm{P}$ and $\mathrm{C}$ are the current premiums on the put and call.

There are several ways to demonstrate the put-call parity theorem. The method most consistent with intuition is to describe the bond in terms of the remaining instruments. The convention with financial instruments is that a plus sign (+) indicates that the instrument is held and a minus sign (-) indicates that it is sold short in the case of the stock, borrowed in the case of a bond, or written in the case of a put or call. Thus, by subtracting $\mathrm{C}$ from both sides, Equation 2 can be rewritten as follows:

$$
P V(E)=S+P-C
$$

Equation 3 shows that a zero-coupon bond that pays $\mathrm{E}$ at date $\mathrm{T}$ is equivalent to a portfolio consisting of stock plus a put and a call written on the stock, with the put and call sharing the same exercise price $(\mathrm{E})$ and maturity date $(\mathrm{T})$. The intuition behind the put-call parity theorem is that the held put ensures that the stockholder will receive at least the strike price, whereas the written call ensures that he will not receive any more. In other words, the stockholder will receive exactly the strike price, which is what a zero-coupon bond pays. ${ }^{24}$

\footnotetext{
$23 \mathrm{PV}(\mathrm{E})$ is the present value of $\mathrm{E}$ to be received at time $\mathrm{T}$.

24 That intuition is demonstrated using a bond that pays $\$ 100$ on March 1, 2009, one share of Google, a put that gives the holder the right to sell one share of Google to the writer for $\$ 100$ on March 1, 2009, and a call that gives the holder the right to purchase one share of Google from the writer for $\$ 100$ on March 1, 2009. A portfolio consisting of one share of Google, a put held on Google at $\$ 100$, and a call written on Google at $\$ 100$, with both the put and the call maturing on March 1 , 2009 , will pay $\$ 100$ on that date regardless of the price of Google on that date. If Google is selling for less than $\$ 100$, the written call will expire worthless. The stock and the put will together be worth $\$ 100$. Alternatively, if Google is selling for more than $\$ 100$, the put expires worthless and the stock and the written call are together
} 
Proof of the put-call parity theorem is through a no-arbitrage argument. If Equation 3 were violated, then arbitragers could borrow using the higher-priced side, invest in the lower-priced side, and pocket the difference. The arbitrager's profit from such a strategy would be guaranteed because at maturity the payoff from the held side of Equation 3 would match the obligation on the borrowed side. ${ }^{25}$ If such riskless profit opportunities were available, arbitragers would want to enter into these transactions as much as possible. Because arbitragers are not earning large and riskless arbitrage profits, it follows that the price of the bond at any date prior to maturity must equal the cost of assembling the equivalent portfolio. That is to say to prevent limitless arbitrage Equation 3 must hold.

worth $\$ 100$ because the written call takes away the increase above $\$ 100$. Finally, if the stock is worth exactly $\$ 100$, the put and call both expire worthless, so the portfolio is again worth $\$ 100$. Therefore, whatever the price of Google at maturity, the portfolio will be worth exactly $\$ 100$. Of course, the financial instrument that provides $\$ 100$ on March 1, 2009, regardless of the price of Google is a $\$ 100$ zerocoupon bond maturing on that date.

25 The notion is that if the portfolio is cheaper than the bond, an investor can make unlimited arbitrage profits by borrowing (shorting the bond) to purchase the portfolio, and conversely. Assume on March 1, 2009, the market price of Google is $\$ 80$, the put premium is $\$ 25$, and the call premium is $\$ 15$. The cost to the investor of purchasing the stock and the put is $\$ 105$ and the investor receives $\$ 15$ for writing the call. Thus, the cost of assembling the portfolio is $\$ 90(\$ 105-\$ 15)$. If the price of the bond on March 1,2009 , is above $\$ 90$, say $\$ 92$, arbitrage is possible: the investor can short the bond (borrow) receiving $\$ 92$ and take $\$ 90$ to assemble the portfolio. The investor will pocket $\$ 2$. On March 1, 2009, she will get $\$ 100$ for her portfolio, which will be just enough to pay principal and interest on the money borrowed. The investor, thus, makes $\$ 2$ on no investment. The investor and many others would like to do as much of this arbitrage as possible. Thus, the price of the bond on March 1, 2009, cannot be above $\$ 90$. Similarly, if the price of the bond on March 1,2009 , is below $\$ 90$, say $\$ 88$, the investor can make an arbitrage profit by shorting the portfolio and purchasing the bond. The investor shorts the portfolio consisting of one share of Google, the put on Google, and the written call on Google by shorting the share, writing the put, and purchasing the call. If the investor follows this strategy, she will receive $\$ 90$. Taking $\$ 88$ to purchase the bond leaves her with $\$ 2$. At maturity, the bond yields the investor $\$ 100$, which she can use to pay the $\$ 100$ owed on the shorted portfolio. Thus, by an argument similar to the one above, the price of the bond cannot be below $\$ 90$. Therefore, it follows that the price of the bond is $\$ 90$, the cost of assembling the original portfolio. 


\section{Extending the Basic Put-Call Parity Relationship ${ }^{26}$}

Equation 3 describes the simplest, and most intuitive, way to avoid usury laws through put-call parity. However, in order to understand the oldest transactions, it is helpful to look at an extension of put-call parity.

Equation 3, which describes the put-call parity theorem, assumes that the underlying stock pays no dividends. ${ }^{27}$ When the underlying stock pays dividends, the right side of Equation 3 is more valuable than the left, because in addition to receiving $\mathrm{E}$ at $\mathrm{T}$, the stockholder also receives dividends. The present value of dividends that will be received on the stock from now until $\mathrm{T}$ is represented by $\mathrm{PV}(\mathrm{D})$. When the stock pays dividends, putcall parity implies that:

$$
P V(E)+P V(D)=S+P-C
$$

Equation 4 states that holding a bond that pays interest is equivalent to a portfolio consisting of dividend-paying stock plus a held put and a written call on that stock. Conceptually, the dividend stream can be thought of as a second bond (PV(D)) that must be added to the zero-coupon bond $(\mathrm{PV}(\mathrm{E}))$ on the left side of the equation for equality to hold.

The zero-coupon bonds described in Equations 3 and 4 above were assumed to have no risk of default. Put-call parity can also be used to represent loans where payment is not assured. There is a class of loans in which the lender agrees not to pursue the borrower personally if the borrower refuses to repay the loan in full. $^{28}$ Instead, the lender takes a security interest in the

\footnotetext{
26 Variations of the put-call parity theorem apply when the stock pays dividends, interest rates vary, and American options replace European options. They are more complex, less intuitive, and often contain inequalities. Moreover, greater generality reduces the tightness of the arbitrage conditions. See ROBERT A. JARROW \& ANDREW RUDD, OPTION PRICING 51-56, 69-79 (1983). However, under more general specifications, there are still strong arbitrage conditions that, if unchecked, would permit the tax and regulatory arbitrage described below.

27 Dividends are periodic payments to the record holder of a share of stock as of the dividend date. Thus, when the stock goes ex-dividend, the price will drop. Most companies do not vary their dividends, so the payments are usually known to investors far in advance.

28 See, e.g., Kemba J. Dunham \& Rachel Emma Silverman, Burned by Real Estate, Some Just Walk Away: But Abandoning Investment Property to Foreclosure Carries a Very High Cost; Slashed Credit Scores, Vulnerable Assets, Wall St. J., Oct. 18, 2007, available at http://online.wsj.com/public/article/
} 
borrower's property. In the event of default, the lender will use the property to satisfy its claim. If the value of the property securing the loan is less than the amount due on the loan, then the lender is out the shortfall. Such a loan is called nonrecourse because the lender has no recourse against the borrower personally if the borrower refuses to pay.

Using option terminology, the lender has written a put to the borrower that allows the borrower to sell the mortgaged property to the lender for the outstanding loan balance. ${ }^{29}$ Rearranging Equations 3 and 4, the put-call parity theorem can be rewritten as:

$$
P V(E)-P=S-C
$$

and

$$
P V(E)+P V(D)-P=S-C
$$

Comparing the left sides of Equations 3 ' and 4' to the left sides of Equations 3 and 4 shows that a lender's payoff from a nonrecourse loan is equivalent to that of a recourse loan plus a put written to the borrower. As Equations 3' and 4' show, putcall parity implies that the lender's payoff from a nonrecourse loan is equivalent to that from owning the mortgaged asset and writing a call on that asset.

\section{II}

\section{RELIGIOUS ROOTS OF THE PROHIBITION ON USURY}

Limitations on the interest rate a lender can charge are widespread. They are also of ancient origin. ${ }^{30}$ Such prohibitions can be traced back to the Pentateuch, or Five Books of Moses. ${ }^{31}$ Perhaps the most famous condemnation of interest comes from Deuteronomy: "Thou shalt not lend upon usury to thy brother;

SB119266868024662861.html ("In a nonrecourse loan, lenders can take only the property itself to satisfy the debt.").

${ }^{29}$ It only makes sense for the borrower to exercise this put if the mortgaged property is worth less than the amount outstanding. If the property is worth more, the borrower is better off selling the property, repaying the loan, and keeping the difference.

${ }^{30}$ For a brief history of usury laws, see Wayne A.M. Visser \& Alastair McIntosh, A Short Review of the Historical Critique of Usury, 8 ACCT., BUS. \& FIN. HIST. 175 (1998).

31 See id. 
usury of money, usury of victuals, usury of any thing that is lent upon usury. Unto a stranger thou mayest lend upon usury; but unto thy brother thou shalt not lend upon usury . ...",32

Deuteronomy thus forbade the ancient Israelites from charging interest on loans to fellow Israelites. However, for loans to outsiders there was no such prohibition: the Israelites were free to charge them interest. ${ }^{33}$

Similar condemnations appear elsewhere in the Pentateuch. For example, Exodus directs, "If thou lend money to any of my people that is poor by me, thou shalt not be to him as an userer, neither shalt thou lay upon him usury." 34

Further, Leviticus contains a lengthy list of rules for the Israelites to follow in their commercial dealings with one another. These rules can be read as exhorting the Israelites to deal fairly and leniently with one another. One passage from Leviticus cautions, "Take thou no usury of him, or increase: but fear thy God; that thy brother may live with thee. Thou shalt not give him thy money upon usury, nor lend him thy victuals for increase." 35

The ancient Israelite's condemnation of interest was later picked up and expanded by both Christianity and Islam. Christianity universalized this prohibition by prohibiting its followers from charging interest on loans made to anyone, Christian or not. ${ }^{36}$ The best-known condemnation of interest in the Gospels is from Luke. The passage exhorts Christians to "lend, hoping for nothing again."

More recently, Islam extended the usury prohibition by prohibiting the faithful from both charging and paying interest.

\footnotetext{
32 Deuteronomy 23:19-20 (King James).

33 Professors Edward Glaeser and José Scheinkman argue that ancient usury prohibitions were a primitive form of social insurance. See Edward L. Glaeser \& José Scheinkman, Neither a Borrower Nor a Lender Be: An Economic Analysis of Interest Restrictions and Usury Laws, 41 J.L. \& ECON. 1 (1998).

34 Exodus 22:25 (King James) (emphasis removed).

35 Leviticus 25:36-37 (King James).

36 See SIDNEY HOMER \& RichARD SYLLA, A HiSTORY OF INTEREST RATES 70 (3d ed. 1996) (noting that Saint Jerome (AD 340-420) is credited with universalizing the prohibition). The antiusury movement reached its zenith in Europe when Pope Clement V (AD 1311) made the ban absolute and declared all secular laws permitting usury null and void. Visser \& McIntosh, supra note 30, at 178.

${ }^{37}$ Luke 6:35 (King James).
} 
The Qur'an contains stern admonitions against riba, most simply, "God has forbidden riba." 38 However, the Qur'an does not explain whether riba, which literally means "increase," refers to all interest, or just unfairly high interest. ${ }^{39}$

The answer to that question comes from the Sunna, which is the second-most important source of religious authority for Muslims. $^{40}$ It contains statements attributed to the Prophet Muhammad that are not contained in the Qur'an. Several passages provide the basis for Islam's broad usury prohibition. The passage that most clearly states that any interest is prohibited reads: "Every loan ... that attracts a benefit is riba."

The most famous passage in the Sunna on riba both prohibits lending at interest and clearly extends that prohibition to paying interest: "Gold for gold, silver for silver, wheat for wheat, barley for barley, dates for dates, salt for salt, each kind for each kind, in hand; he who increases or asks for increase commits [r]iba ..., alike whether he gives or takes."

III

\section{MUSLIMS AND THE AMERICAN DREAM}

Islam's prohibition on paying interest has made it difficult for many Muslims living in the West to purchase a home. ${ }^{43}$ As a

38 Qur'an 2:275. The quotation in the text is from a translation provided by Chibli Mallat, The Debate on Riba and Interest in Twentieth Century Jurisprudence, in ISLAMIC LAW AND FINANCE 69, 69 (Chibli Mallat ed., 1988).

39 See Frank E. Vogel \& SAMUel L. Hayes, III, ISLAMic LaW AND FinanCE: RELIGION, RISK, AND RETURN 72-73 (1998).

40 M. KABIR HASSAN \& MERVyN K. Lewis, Glossary, in HANDBOOK OF ISLAMIC BANKING xviii (M. Kabir Hassan \& Mervyn K. Lewis eds., 2007).

41 The quotation in the text is from a translation provided by VOGEL \& HAYES, supra note 39 , at 73 .

42 The quotation in the text is from a translation provided by Mallat, supra note 38, at 69 n.1 (emphasis added).

43 See Neal Gendler, Finance Methods Could Allow More Muslims to Own Homes: Several Groups Are Looking for Ways to Help Minnesota's Growing Muslim Population Buy Homes Without Violating Islamic Principles, STAR TRIB. (Minneapolis), May 19, 2000, at 5B; Yuki Noguchi, Matching Faith and Finances: Alternatives to Loans Cater to Area Muslims, WASH. Post, Oct. 28, 1999, at E1; Alison Steed, Midweek Money: Borrow in Good Faith; A New Scheme Offers Muslims Mortgage Loans That Don't Break Islamic Law, INDEP. (London), Feb. 3, 1999, at 11. Observant Muslims need to have enough cash to pay the full purchase price, whereas the typical U.S. home buyer provides ten percent, or even as little as five percent, of the purchase price to qualify for a mortgage. 
result, this prohibition has spurred some innovative home financing techniques that use put-call parity. In one transaction, the bank buys the house and sells it to its client for a higher price through an installment sale. ${ }^{44}$ Thus, instead of owning the house (S) and taking out a mortgage (-PV(E)), which would be written as $S-P V(E)$, the client has agreed to buy the house in the future for $\mathrm{E}$, which can be written as $C-P{ }^{45}$ Although the two transactions are in substance equivalent, they differ in form. From the bank's perspective, it owns the house (S) subject to the agreement to sell it to its client $(-C+P)$. Thus, the bank's position, which can be written as $S-C+P$, is from put-call parity equivalent to $\mathrm{PV}(\mathrm{E})$, a simple loan. ${ }^{46}$

This simple cost-plus profit financing transaction is called murabaha. While murabaha transactions have traditionally been used for trade finance, ${ }^{47}$ they are now also being used to provide home mortgages. ${ }^{48}$ As illustrated above, the murabaha contract uses Equation 3 (or Equation 3' if it replicates a nonrecourse loan) to avoid usury. ${ }^{49}$

The murabaha transaction also raises many potential legal issues, such as whether the bank as an owner of the property can be held liable in environmental litigation, whether the bank is a mortgage lender and subject to the applicable laws, whether the bank's income is interest or capital gain, and whether the bank can use the installment method to report gain (which is available

44 See Adam Jones, No-Interest Loan Has Poor Take-Up, Times (London), Jan. 17, 1998, at G4.

45 Technically, the contract is not a simple forward, but a series of forward contracts. In a forward contract, the holder is obliged to purchase the underlying asset from the writer. Thus, a held forward combines a held call and a written put, so it can be written as $C-P$.

46 If the bank cannot force its client to later pay for the house, then the client has a call (C), which is equivalent to owning the house and financing it with a nonrecourse mortgage $(S-P V(E)+P)$. The bank holds the property subject to a call $(S-C)$, which is equivalent to holding a nonrecourse mortgage $(P V(E)-P)$.

47 Tarek S. Zaher \& M. Kabir Hassan, A Comparative Literature Survey of Islamic Finance and Banking, 10 FIN. MARKETS, INST. \& INSTRUMENTS 155, 160 (2001).

48 E.g., Jones, supra note 44.

49 The murabaha transaction uses the simpler versions of put-call parity without dividends because the bank's profit comes from the difference between the purchase price and sales price. 
only for capital gains). ${ }^{50}$ The murabaha also provides the bank with a higher rate of return if the client sells the house before the bank is repaid in full because the client must repay the bank early. If the sale occurs very soon after purchase, the transaction could violate state usury laws if those laws treat the transaction as a covered loan. ${ }^{51}$

In a slightly more complicated variation, the bank buys the house and enters into a contract to sell it to the client for the same price in a series of installment payments over a number of years. The bank also agrees to rent the client that portion of the house the client does not own. ${ }^{52}$ If the client fails to make the payments, the bank will take over the house and sell it. Thus, the client has the option to buy the entire house by making all of the payments $(\mathrm{C}) .^{53}$ Put-call parity implies that this transaction is equivalent to the client owning the house $(\mathrm{S})$ and financing it with a nonrecourse mortgage $(-P V(D)-P V(E)+P) .^{54}$ From the bank's perspective, it owns the house, has rented it, and has written a call on it $(S-C)$, which is economically equivalent to making a nonrecourse loan with the house as collateral $(P V(D)+P V(E)-P)^{55}$

The above leasing transaction with an option to purchase is called an ijara wa-iqtina. It is similar to a financial lease with an

50 See Zaher \& Hassan, supra note 47, at 160 (raising similar legal questions in the context of trade finance).

51 In effect, the murabaha provides for a predetermined amount of interest. If the loan is repaid early, the effective periodic interest rate is increased. See HASSAN \& LEWIS, supra note 40, at 320.

52 Noguchi, supra note 43. If the rental rate is fixed, the transaction is similar to a fixed-rate mortgage; if the rental rate varies over time, it is similar to a variable rate mortgage. See Steed, supra note 43, at 11; Marla Dickerson, The Price of Piety in Islam, L.A. TIMES, Mar. 17, 1999, at A1.

53 Technically, this is not a single option, but is a series of embedded options. Each month, the client has to decide whether to make the next payment, in which case it has the right to continue to make payments, or to stop making payments. If it chooses the latter, the bank takes the property and presumably sells it.

54 The borrower's right to walk away from the transaction by transferring the property to the lender is the right to sell the property to the lender for the outstanding balance of the loan. Thus, this right is a put option.

55 If the bank can force its client to later purchase the house, then the client has also written a put, which leaves it in position $C-P$, which is equivalent to owning the house and financing it with a recourse mortgage $(S-P V(D)-P V(E))$. The bank holds the property subject to a call and holds a put $(S-C+P)$, which is equivalent to holding a recourse mortgage $(P V(D)+P V(E))$. 
option to purchase. ${ }^{56}$ In contrast with the murabaha transaction, it uses Equation 4 (or Equation 4' if the bank is replicating a nonrecourse loan) because the client pays rent to the bank. This rent is $\mathrm{PV}(\mathrm{D})$ in Equation 4 (and Equation 4'). As with the murabaha, the ijara wa-iqtina raises similar legal issues because the bank holds title to the land. ${ }^{57}$ One advantage of the ijara wa-iqtina over the murabaha is that the ijara wa-iqtina does not result in an excessively high implicit interest rate if the occupant sells the house soon after moving in. This is because the bank's profit from this rent-to-purchase transaction comes from the rent it receives. Because repurchasing the house ends the obligation to pay rent, an early repurchase reduces the total implicit interest in the transaction.

Islamic mortgage substitutes raise significant regulatory questions. In the United States, commercial banks are generally prohibited from owning real estate other than their own premises. $^{58}$ As a result, experts questioned whether Islamic home mortgage substitutes, which avoid the prohibition on interest by transferring ownership to a bank, were consistent with U.S. banking laws. ${ }^{59}$ About ten years ago, the Office of the Comptroller of the Currency ("OCC"), which regulates commercial banks, addressed that question directly. In 1997 and 1999, it issued two rulings to the United Bank of Kuwait approving Islamic real estate financings. ${ }^{60}$ In approving the products, the OCC looked past the forms of the transactions to their substance and recognized that in substance these transactions were "functionally equivalent to or a logical outgrowth of" preexisting approved financial products. ${ }^{61}$ In effect, the OCC was using put-call parity when it recognized

56 See Zaher \& Hassan, supra note 47, at 160.

57 See id. at 161 (raising these questions in the context of capital leases).

5812 U.S.C. $\S 29$ (2008).

59 See Thomas C. Baxter, Jr., Regulation of Islamic Financial Services in the United States (Mar. 2, 2005), available at http://newyorkfed.org/newsevents/ speeches/2005/bax050302.html.

60 Off. Comptroller Currency Interpretive Letter No. 806 (Oct. 17, 1997) [19971998 Transfer Binder] Fed. Banking L. Rep. (CCH) If 81,253 (Islamic home financing leases); Off. Comptroller Currency Interpretive Letter No. 867 (June 1, 1999) [1999-2000 Transfer Binder] Fed. Banking L. Rep. (CCH) If 81,361 (murabaha financing products).

61 See Baxter, supra note 59. 
that, in spite of their form, the transactions were in substance lending transactions.

In contrast with the OCC, which has provided explicit public guidance on Islamic financial products, the Treasury has not provided any such guidance. ${ }^{62}$ Yet some Islamic financial services institutions claim that a portion of the individuals' payments will be deductible as interest on home mortgage indebtedness and send Forms 1098 to their clients, presumably relying on opinions from their lawyers that these transactions are in substance loans at interest. ${ }^{63}$ The argument that these transactions should be treated similarly to other mortgages is the argument that substance should trump form and that in substance these transactions are interest-bearing loans. Once again, the economic equivalence of Islamic financial transactions and traditional real estate mortgages is an application of put-call parity.

Regardless of how these transactions are reported on the parties' tax returns, Muslims who finance their homes through these transactions seek assurances that they are not paying interest in violation of shari'a. Accordingly, both murabaha and ijara wa-iqtina transactions are supported by opinions from clerics and scholars that these transactions are consistent with shari'a. ${ }^{64}$ These opinions typically focus on the transaction's form, which does not provide for any explicit interest. Nonetheless, some experts believe these transactions are impermissible disguised loans. ${ }^{65}$ These critics are implicitly using put-call parity to look through these transactions. ${ }^{66}$

62 The research librarians at the University of Pennsylvania and I could not find any explicit cases or rulings on the taxation of Islamic financial products. A similar search conducted by Joel Newman several years earlier turned up no direct sources. Joel S. Newman, Islamic and Jewish Perspectives on Interest, 89 TAX NOTES 1311, 1317 (2000). Such rulings are mentioned or implied in some news stories. E.g., Cathleen Falsani, The American Dream: Lease-to-Own Company Could Ease Tensions, DAILY SOUTHTOWN (Ill.), Sept. 13, 1999; Noguchi, supra note 43.

63 See Newman, supra note 62, at 1312.

64 See Paul Slade, Family Finance: Ethical Mortgages for Muslims, SUNDAY TELEGRAPH (London), Feb. 14, 1999, at 11.

65 See Dickerson, supra note 52 ("Islamic banking isn't without its critics, most of whom are Muslims wary of financial institutions using religion as a marketing tool. Some view the 'fees,' 'markups,' and 'profit-sharing,' of Islamic transactions as a thinly veiled subterfuge for interest."). For discussions of shari'a boards-groups of scholars that opine on whether financial contracts are consistent with Islamic principles-see Michael McMillen, Islamic Capital Markets, Developments and 
IV

\section{THE DEVELOPMENT OF THE MORTGAGE IN MEDIEVAL ENGLAND}

Today, London is a major banking center, and the London Inter-Bank Offered Rate ("LIBOR") is a benchmark interest rate for financial transactions. ${ }^{67}$ It has not always been that way. The medieval Church prohibited lenders from charging any interest at all. ${ }^{68}$ To satisfy the dictates of both church and finance, the following arrangement became standard in feudal England where land was one of the few assets that could secure a loan. A landholder would transfer legal title (a fee interest) to a financier in exchange for cash. The transfer would be made subject to the condition that the original landholder could reclaim his land by repaying the financier on a predetermined and contractually set date, called law day. ${ }^{69}$ The return to the financier, excluding any gain if the land was not reclaimed, came from taking possession of the land and collecting rents and profits generated by the land. ${ }^{70}$ If, however, the original landholder failed to reclaim the land on law day, the financier kept the land. ${ }^{71}$

Issues, 1 CAPITAL MARKETS L.J. 136, 139-41 (2006); M. Umer Chapra \& Habib Ahmed, Corporate Governance in Islamic Financial Institutions (Islamic Dev. Bank, Occasional Paper No. 6, 2002); Wafik Grais \& Matteo Pellegrini, Corporate Governance and Sharrah Compliance in Institutions Offering Islamic Financial Services (World Bank Policy, Working Paper No. 4054, Nov. 2006).

66 See generally Mahmoud A. El-Gamal, "Interest" and the Paradox of Contemporary Islamic Law and Finance, 27 FORDHAM INT'L L.J. 108, 109 (2003) (criticizing Islamic jurists who condemn traditional interest-based financing while profiting from its Islamic twin).

67 Gillian Tett, Libor's Value Is Called into Question, FIN. Times, Sept. 25, 2007.

68 Visser \& McIntosh, supra note 30, at 178.

69 For discussions of this medieval English land transaction, see GRANT S. Nelson \& DALE A. WhitMan, ReAl Estate FinANCE LAW 6-9 (3d ed. 1994); Steven Wechsler, Through the Looking Glass: Foreclosure by Sale As De Facto Strict Foreclosure-An Empirical Study of Mortgage Foreclosure and Subsequent Resale, 70 CORNELL L. REV. 850, 855-56 (1985).

70 NELSON \& WHITMAN, supra note 69 , at 7.

${ }^{71} \mathrm{Id}$. Because the financier did not have the right to put the land back to the original owner, the transaction was the equivalent of a nonrecourse mortgage. Without the put, the financier's position is $S-C$, which is equivalent to $P V(E)-P$. The medieval lending transaction closely follows the put-call parity theorem: the transfer of the land for cash is the purchase of the underlying asset by the lender $(\mathrm{S})$, and granting the borrower the right to redeem is the writing of a call (-C). 
From the perspective of the financier, the financier owned and wrote a put on the land $(S-C)$. Through put-call parity, this transaction was equivalent to making a nonrecourse loan $(P V(D)+P V(E)-P)$. In this formulation, $\mathrm{PV}(\mathrm{E})$ represents the loan principal and $\mathrm{PV}(\mathrm{D})$ represents the rents and profits generated from the land. The original landowner held a call on the land (C), which is equivalent to owning the land subject to a nonrecourse interest-bearing mortgage $(S-$ $P V(D)-P V(E)+P)^{72}$

The above medieval financial transaction is the predecessor to the modern real estate mortgage. ${ }^{73}$ The financier was allowed to keep the land if the original landowner did not pay on law day, even if the original landowner was not at fault for the failure. For example, if the financier was unavailable on law day, he could keep the land because the law courts read these contracts to make time of the essence. Although the law courts would not intervene on behalf of the original landowner, the English Chancery Court would. The English Chancery Court granted relief to original landowners who were only slightly late in tendering and established specific equitable grounds, such as fraud. The English Chancery Court then required that the financier accept the tender and transfer the property back. By the seventeenth century, the intervention of the equity courts was routine. Selling landowners had the right to redeem their land from their purchasers by tendering principal and interest within a reasonable time after law day and without establishing explicit equitable grounds. This right to late redemption, which is now known as the equity of redemption, was the first mortgagor protection law. ${ }^{74}$

The equity of redemption, however, created a problem. It imposed an indefinite cloud on mortgagees' titles, discouraging mortgagees from improving their land and making it difficult to

72 The transaction uses Equation 4', not Equation 3', because the land generates the return to the financier.

73 In some states, mostly in the Southeast, the mortgagee has legal title to the mortgaged real estate. However, in the majority of states, the mortgagor retains title. Nelson \& WhitMan, supra note 69, at 7; 4 POWELl on REAL PROPERTY $\S$ 37.03 (Richard R. Powell \& Patrick J. Rohan eds., 1997).

74 NELSON \& WHITMAN, supra note 69, at 7. 
transfer land. ${ }^{75}$ The need for the mortgagee to be free from the mortgagor's right to redeem after a reasonable time led the equity courts to develop the mortgagee's right to foreclose the mortgagor's equity of redemption. Such foreclosure, when granted by a court of equity, forever cut off the mortgagor's right to redeem. ${ }^{76}$ The defining characteristic of a mortgage is this equity of redemption and the requirement that a mortgagee foreclose that equity before the mortgaged property can be used to satisfy the debt.

As the above paragraphs illustrate, there were two significant differences between a formal loan, the left side of Equation 4', and a synthesized loan, the right side of Equation 4'. First, the formal loan at interest was prohibited as usurious, whereas the economically equivalent synthesized loan was not. Second, the financier had greater rights in the event of default with the synthesized loan than with the formal loan. For example, if the borrower on a formal loan defaulted, the lender had to sue the borrower to collect. $^{77}$ The lender could not seize the defaulting borrower's property. In contrast with the formal loan, the financier held title to the land with the synthesized loan. That title would indefeasibly vest if the loan was not repaid in full on law day. Although that additional security might have been one reason for using a synthesized loan, the prohibition on usury made formal loans with interest impossible. Thus, the difference in substantive rights between the two economically equivalent transactions became important. It was in reaction to these legal rights, and the perception that the rights that the financier held with the synthesized loan were unfair to the original landowner, that the English Chancery Court created the equity of redemption and required the foreclosure of that interest. In this

75 The title is not improved by transfer. The transferee can only receive the title held by the transferor.

76 This form of foreclosure is called strict foreclosure because the land is forfeited to the mortgagee. Strict foreclosure is rarely used in the United States today. Foreclosure in the United States is by sale and any proceeds generated by the sale above what is owed the mortgagee are used first to satisfy other secured creditors of the mortgagor and thereafter paid to the mortgagor. NELSON \& WHITMAN, supra note 69 , at 9 .

77 Such a suit would have been brought in the law court and would have been subject to the slow process and technical pleading requirements of those courts and times. 
way, put-call parity played a crucial role in the development of the modern mortgage.

However, the use of put-call parity to avoid the prohibition on usury goes back still further. Almost the identical transactional structure was used fifteen hundred years earlier.

\section{$\mathrm{V}$}

\section{ANCIENT ISRAEL, DEUTERONOMY, AND THE TALMUD}

The Talmud is the summary of the oral law of the Jews that had evolved over centuries. ${ }^{78}$ It was written by sages who lived in Palestine and Babylon roughly two thousand years ago and contains two main components: the Mishnah, a book of law, and the Gemerah, a commentary upon that law. ${ }^{79}$ The Mishnah deals with a wide range of subjects. Many of these subjects are principally religious, such as prayers, the Sabbath, festivals, rituals, and dietary laws. Other subjects are primarily secular. One of the latter topics is civil law, often called monetary law.

Monetary law was a particularly rich area for discussion. The sages recognized that many matters of purely religious law could remain unchanged for long periods, but monetary law must change to keep up with the times. ${ }^{80}$ As a result, the Talmud took the few monetary laws recorded in the Torah and elaborated and adopted those laws for contemporary circumstances. ${ }^{81}$ The monetary laws are divided into three parts, called gates. The first deals with harms inflicted by one person upon another, what we call torts; a second deals with partnerships, sales, and legal documents; and a third deals with disputes over money and loans.

The second gate is called the Baba Metzia and many of its entries deal with attempts to evade the prohibition on usury. Thus, there is a series of passages holding many interestavoidance transactions to be usurious. For example, one cannot make an interest-free loan of money and simultaneously require the borrower to perform service or provide free or reduced-cost lodging. ${ }^{82}$ Such prohibitions, although important for maintaining

\footnotetext{
78 Adin Steinsaltz, THE Essential TAlMud 3-4 (1976).

79 Id. at 4.

80 Id. at 145.

81 Id. at 146.

82 Mishnah Baba Metzia 5:2 (Herbert Danby trans., Oxford University Press).
} 
the usury prohibition, do not implicate put-call parity. However, elsewhere in the Mishnah, there is a discussion that touches upon put-call parity. The relevant passage reads: "If a man sold a house from among the houses in a walled city, he may redeem it at once and at any time during twelve months. This is a kind of usury, which is yet not usury." 83

The above passage deals with a practice that allowed individuals who sold their houses out of financial need to reclaim their houses if they repaid the purchaser within a year. This practice comes from a passage in Leviticus that reads as follows:

If a man sells a house in a walled city, he retains the right of redemption a full year after its sale. During that time, he may redeem it. If it be not redeemed within the space of a full year, then the house that is in the walled city shall be established for ever to him that bought it throughout his generations ....

When read in conjunction with the passage from Leviticus, the Mishnah passage indicates that the sages understood that the sale and later redemption of a house (at the same price) provides the purchaser with interest in the form of implicit services (the shelter provided by the house that the purchaser would otherwise have to acquire by renting another house). This is what is meant by the phrase, "[t]his is a kind of usury." However, the sages concluded that the transaction could not be prohibited. Their unstated, but obvious, reason was that the right of redemption was explicitly provided in Leviticus.

Moreover, the sages in the passage from the Mishnah ask the put-call parity question: is a transaction that pays interest in substance but not in form prohibited? The sages understood that a seller who redeems his house has implicitly paid interest to the buyer in the form of the services provided by the house. The sages further understood that the sale with a right to redeem was the economic equivalent of an impermissible loan. ${ }^{85}$ The passage further suggests that the sages might have condemned the practice if it was not explicitly approved in Leviticus. Thus, at some level the rabbis of the Talmud had an intuitive understanding of put-call parity.

\footnotetext{
83 Id. Arakhin 9:3 (footnotes omitted).

84 Leviticus 25:29-30 (King James).

85 The logic was described in supra Part IV in connection with the medieval transaction.
} 
An especially interesting passage immediately follows the passage from the Mishnah quoted above:

If the [last] day of the twelve months was come and it was not redeemed, it became his for ever, no matter whether he bought it or was given it was a gift, for it is written, [i]n perpetuity. Beforetime the buyer used to hide himself on the last day of the twelve months so that [the house] might be his for ever; but Hillel the Elder ordained that he [that sold it] could deposit his money in the [Temple] Chamber, and break down the door and enter, and that the other, when he would, might come and take his money.

The abuse, and its resolution, in the above passage is strikingly similar to the English experience fifteen hundred years later. ${ }^{87}$ The tendency for some buyers to hide from redeeming sellers strongly suggests that some buyers and sellers understood that these transactions were intended to be loans. They appeared to have an intuitive sense of this relationship and understood the equivalence between an impermissible loan and a permissible sale followed by a redemption. Moreover, this intuition was used to develop a transaction that was able to withstand scrutiny because the authorities could not prohibit the synthesized loan since it was explicitly approved in Leviticus. Thus, the intuition that underlies put-call parity was likely being used more than two thousand years ago to engage in regulatory arbitrage.

\section{VI}

\section{THE MODERN PROHIBITION ON CLOGGING THE EQUITY OF REDEMPTION}

More recently, some lenders have used put-call parity to try to evade mortgagor protection laws. ${ }^{88}$ Modern mortgage lenders rarely attempt to avoid the prohibition on usury because the

\footnotetext{
86 Mishnah, supra note 82, Arakhin 9:4 (some alterations added) (emphasis omitted).

87 Rabbi Hillel, the Elder's resolution in Mishnah Arakhin 9:4, can be thought of as the forerunner of the equity of redemption.

${ }^{88}$ For discussions of the range of devices employed by lenders to avoid foreclosure and of the aggressiveness of courts in preventing such clogging, see Nelson \& WhitMan, supra note 69, at ch. 3; John C. Murray, Clogging Revisited, 33 ReAl PRop. PROB. \& TRUST J. 279 (1998).
} 
maximum legal interest rate is usually well above market rates. ${ }^{89}$ However, many lenders are interested in cutting off the mortgagor's equity of redemption and other mortgagor protections. ${ }^{90}$

The right of a mortgagor to redeem after default and the requirement that the mortgagee foreclose are considered inseparable incidents of the mortgage. ${ }^{91}$ The parties cannot legally contract around these rights. ${ }^{92}$ In addition, there are a plethora of statutory mortgagor protection provisions that vary from state to state. These include statutory (post-foreclosure) redemption, fair value legislation, prohibition of deficiency judgments, and the one-action rule. ${ }^{93}$ While the wisdom of requiring such mortgagor protections has been questioned, ${ }^{94}$ all states impose one or more forms of protection. ${ }^{95}$ Over the years,

89 Modern mortgage interest rates do not bump up against usury laws as they did in the late 1970s and early 1980s. See, e.g., Steve Frazier, Texas Lenders and Home Builders Assail Law Setting Floating Rates on Mortgages, WALL ST. J., Oct. 12, 1979; Jonathan Kaufman, Mortgage Lending Dries Up in Midwest Due to Fed's Actions and Usury Statutes, WALL ST. J., Oct. 15, 1979 ("Twenty-two states, including Iowa, Illinois and Wisconsin, have usury laws that currently keep mortgage interest rates below $12 \%$. The Federal Home Loan Bank of Chicago . . . lends S\&Ls money at $13.5 \%$.... 'There's no way S\&Ls can make money on mortgages if they then charge $12 \% . " ”)$.

90 When a mortgagor defaults, the lender cannot take the mortgaged property and sell it to satisfy the claim. In most jurisdictions, the mortgagor cannot even evict the mortgagee immediately. Instead, the mortgagor remains in possession of the property and has a period of time to cure the default. Only once the right to cure the default, the equity of redemption, has expired can the mortgagee go to court and get an order foreclosing the equity of redemption. In the United States this results in a public sale of the property. The proceeds of the sale are used to pay the mortgagor's obligation to the mortgagee and other secured creditors of the mortgagor after which any excess is returned to the mortgagor.

91 AM. LAW InST., RESTATEMENT (THIRD) OF PROPERTY § 3.1(a), (b) (1997) (the mortgagor in default has the right to redeem the real estate until a valid foreclosure and any agreement limiting that right is normally ineffective).

92 Roger A. Cunningham \& Saul Tischler, Disguised Real Estate Security Transactions As Mortgages in Substance, 26 RuTGERS L. REV. 1, 7 n.20 (1972). This is known as the prohibition on clogging the mortgagor's equity of redemption.

93 Usually, these protections cannot be waived when the mortgage is created, although they frequently can be waived at a later date. NELSON \& WHITMAN, supra note 69, at 41.

94 See Michael H. Schill, An Economic Analysis of Mortgagor Protection Laws, 77 VA. L. REV. 489, 496-98 (1991) (sources cited in footnotes). Professor Schill is more sanguine about such protections. Id. at 498-500 (mortgagor protection laws promote efficiency as a form of insurance for the risk averse).

95 See id. at 492 n.6 (stating that, for example, only Connecticut and Vermont permit strict foreclosure and even those states have other mortgagor protections). 
many mortgagees have tried to avoid the mortgagor's equity of redemption and statutory mortgagor protections by taking title to the land and agreeing to transfer it to the borrower in exchange for repayment. The use of an absolute deed with some form of collateral agreement for reconveyance upon payment is often intended to eliminate the grantor's equity of redemption and avoid statutory mortgagor protections. ${ }^{96}$

For example, if a lender and a borrower agree that the lender will make a one-year $\$ 100,000$ recourse loan to the borrower at ten percent to be secured by land owned by the borrower, the parties can accomplish this result and avoid a formal loan in two different ways. First, the original landowner can sell the land to the financier for $\$ 100,000$, write a put to the financier at $\$ 110,000$, and the financier writes a call to the seller at $\$ 110,000$ (this is the right side of Equation 3). ${ }^{97}$ Alternatively, the landowner can sell the land for $\$ 100,000$ and the buyer can rent the land to the seller, or someone else, for $\$ 10,000$ (at the end of the year). In this transaction, the puts and calls are written at $\$ 100,000$ (this is the right side of Equation 4). ${ }^{98}$ In both transactions, put-call parity is being used in an attempt to evade the impact of mortgagor protections.

If merely changing the form of the transaction could negate mortgagor protection provisions, then put-call parity would provide an easy escape. However, courts are aware of disguised mortgage transactions and will treat as mortgages those transactions that are in substance, although not in form, loans. ${ }^{99}$ This position, which goes back to the late nineteenth century, ${ }^{100}$ is based on put-call parity inasmuch as the court recognizes such a transaction as the economic equivalent of a loan, which suggests that the court grasps, at least intuitively, put-call parity.

96 See Nelson \& Whitman, supra note 69, at ch. 3; Cunningham \& Tischler, supra note 92, at 1-2. The collateral agreement can be oral or written. Cunningham \& Tischler, supra note 92, at 1.

${ }^{97}$ If the goal is to synthesize a nonrecourse loan, there is no put and the form of the transaction is given by the right side of Equation 3'.

98 Once again, if there is no put, the transaction is equivalent to a nonrecourse loan and the form of the transaction is given by the right side of Equation 4'.

99 Cunningham \& Tischler, supra note 92, at 1-2.

100 The leading case is Pace v. Bartles, 20 A. 352, 359 (N.J. Ch. 1890). 


\section{CONCLUSION}

Recent years have seen an explosion of financial innovation. ${ }^{101}$ Much of this innovation seeks to exploit inconsistencies in the regulatory environment, ${ }^{102}$ and one popular technique that has frequently been used for regulatory arbitrage is put-call parity. ${ }^{103}$ Although put-call parity was first formally described only forty years ago, ${ }^{104}$ for some time, economic historians have recognized that some people appear to have had an intuitive understanding of put-call parity before that relationship was formally described. Nonetheless, scholars who study the history of financial innovation had not traced the use of put-call parity back very far. In this Article, I trace regulatory arbitrage using put-call parity back to ancient Israel. ${ }^{105}$ Two thousand years ago, financiers in ancient Israel used put-call parity to evade the prohibition on charging interest. Five hundred years ago, English financiers did the same, which led to the development of the modern mortgage. And today, Muslims living in the West use mortgage substitutes that rely on put-call parity to avoid violating Islam's prohibition on paying interest. In addition, financiers sometimes try to avoid the equity of redemption and statutory mortgagor protections using put-call parity. Although modern observers might recognize all of these transactions as applications of putcall parity, the ancient and medieval users of these transactions had not heard of put-call parity. Yet, at some level some of them must have understood the intuition behind put-call parity because they developed, used, and debated the legality of transactions based on that relationship.

No doubt, many significant financial innovations are distinctly modern. However, others, including the use of put-call parity for regulatory arbitrage, are of ancient origin.

\footnotetext{
101 See supra notes 1-17 and accompanying text.

102 MiLleR, supra note 8, at 5-9.

103 Knoll, supra note 17.

104 See Stoll, supra note 15.

105 See Ross, WESTERFIELD \& JAFFE, supra note 18, at 621.
} 